\title{
LANDSCAPE FRAGMENTATION AND FIRE VULNERABILITY IN PRIMARY FOREST ADJACENT TO RECENT LAND CLEARINGS IN THE AMAZON ARC OF DEFORESTATION
}

\author{
Ernesto Alvarado ${ }^{1}$ \\ David V. Sandberg ${ }^{2}$ \\ Joao Andrade de Carvalho Jr. ${ }^{3}$ \\ Ralf Gielow \\ José Carlos Santos ${ }^{5}$
}

\begin{abstract}
RESUMEN
Deforestación extensiva en el Amazonas ha creado una selva bastante fragmentada en regiones con tasas altas de deforestación y de uso del fuego para limpia y mantenimiento de terrenos. El bosque en la interfase con estas deforestaciones sufre cambios drásticos en microclima, vegetación y procesos ecológicos, los cuales son favorables para la combustión bajo las copas después de una sequía prolongada. Un incremento en el uso del fuego, aunado a una mayor área de bosque vulnerable a incendios es una amenaza para la integridad y sustentabilidad de selvas tropicales. Se presentan resultados de estudios conducidos en Mato Groso de 1997 al 2003 como parte de experimentos para estudiar combustión de biomasa, tasas de liberación de carbono y flamabilidad de selvas. Se monitorearon cambios en susceptibilidad a incendios en la interfase entre el bosque y áreas recientemente deforestadas durante la temporada de sequía, al final de la cual se desarrollaron quemas experimentales.

Palabras Clave: Incendios tropicales, fragmentación, microclima, selva primarias.
\end{abstract}

\begin{abstract}
Extensive deforestation in the Amazon has created a highly fragmented forest in regions with an extensive rate of land use conversion and use of fire for land clearing, agriculture and grassland maintenance. The forest on the interface with land clearings suffers drastic changes in micro weather, vegetation, and ecological processes. Those altered conditions are favorable to sustaining understory fires after a prolonged drought. An increasing amount of fire usage, coupled with large areas of forest vulnerable to fire creates a new threat to the integrity and sustainability of the tropical forests in Amazonia and elsewhere in the tropical world. This paper presents the results of experimental burnings conducted from 1997 to 2003 in Mato Grosso. The study monitored the change in vulnerability of the interface between primary forest and recent deforested patches, monitored fire behavior and depth of fire penetration in the undisturbed forest on the edge of land clearing.

Keywords: Tropical fires, fragmentation, microclimate, primary forest
\end{abstract}

\section{INTRODUCTION}

Tropical forests throughout the world are disappearing or deteriorating to a very rapid pace. Among the most significant causes is the change in land use by the conversion of land use to agriculture, pasture, or urbanization. Selective logging and natural factors also account for a large portion of it. Although there are efforts to curtail the rapid loss of such forests, there is a disturbing increasing trend of tropical forest loss. Gains from those programs seem only temporary. For instance, massive deforestation occurred in the Brazilian Amazon forest during the 1970s and 1980s. Deforestation slowed down on the 1990s due to Brazil's government policies. However, recent assessments show an increase again and now with different spatial patterns than before (Skole and Tucker 1993, INPE

\footnotetext{
${ }^{1}$ Dr. Investigador del College of Forest Resources, University of Washington, CFR-UW Mailbox 352100. Seattle, Washington 98195 USA. alvarado@u.washington.edu.

${ }^{2}$ Dr. Líder del Grupo Investigaciones Aplicadas en Fuego y Medio Ambiente. Estación Experimental del Pacifico Noroeste del US Forest Service, 3200 SW Jefferson Way Corvallis, OR 97331, USA. dsandberg@fs.fed.us.

${ }^{3}$ Dr. Profesor. Departamento de Ingeniería Mecánica de la Universidade Estatal Paulista, Av. Ariberto Pereira da Cunha 333. 12516-410, Guaratinguetá, SP, Brasil. joao@feg.unesp.br.

${ }^{4}$ Centro de Predicción del Tiempo y Estudios Climáticos. Instituto Nacional de Pesquisas Espaciáis, Rodo vía Presidente Dutra Km 40. 12630-000, Cachoeira Paulista, SP, Brasil. ralf@cpetec.inpe.br.

${ }^{5}$ Laboratorio Asociado de Combustión y Propulsión. Instituto Nacional de Pesquisas Espaciáis, Rodo vía Presidente Dutra Km 40. 12630000, Cachoeira Paulista, SP, Brasil. jcarlos@1cp.inpe.br.
} 
2002, INPE 2003, Laurance et al. 2001).

Occurrence of catastrophic wildfires in the last few decades in different parts of the world has raised awareness of devastating local and regional effects and the potential impact across international borders. In addition, a steady increase of wildfire risk has been detected in the last couple of decades in temperate and tropical ecosystems. Noticeably, uncontrollable wildfires in the tropics have increased in number and extent at rates higher than temperate forests. Ordinarily, undisturbed tropical rain forest is considered a fireproof ecosystem, however, severe fires occur during sustained droughts when the ecosystem is dry enough to sustain smoldering combustion, or when the canopy is disturbed by natural events or human activities. Those climate and forest conditions are concurring more often in the tropical world.

The 1998/99 wildfire seasons in Mexico, Central America, Brazil, and other countries signaled how vulnerable tropical ecosystems are becoming to wildfires and that the immediate effects are felt across borders. The tropical southern Mexico and the state of Roraima in the Brazilian Amazon were heavily impacted during that wildfire season (Cairns and others 1998; Kirchhoff and Escada 1998). Extensive damage has also been observed in several parts of the Amazonian forest. These severe and extensive wildfires are a threat to the integrity, biodiversity and sustainability of tropical forests around the tropical world. Those severe fire seasons also have shown that some land use/land cover types are more vulnerable than other types and that generalizations cannot be made on flammability or carbon emissions from tropical ecosystems.

Forest wildfires that start form from escaped agriculture and rangeland fires are becoming more common throughout the tropical world. Fire has been observed to spread under the canopy for long distances and smolder for long periods on rotten trunks where it can remain active for long periods. Those accidental fires cause approximately one-half of the area burned in the Amazon forest of Brazil, and are often associated fires that start in adjacent areas cleared for agriculture or transportation corridors (Nepstad and others 1999, Uhl and Kauffman 1990)

\section{OBJECTIVES AND STUDY AREA}

The Fire and Environmental Research Team (FERA) of the US Forest Service, Seattle, Washington is engaged in cooperative programs on wildfires in the United States, Brazil, Mexico, and Bolivia. The research is directed to develop a globally consistent decision support system for fire management, ecosystem restoration, and global change response to wildfires. Participants of these cooperative projects include researchers and students from the two countries since 1997 and has included studies on flammability assessment of primary, logged and fragmented tropical forest, prediction of biomass consumption and smoke emissions from fires in tropical ecosystems, and development of a thermodynamic model of flaming, smoldering, and residual combustion.

This paper presents the results of a flammability study conducted from 1998 to 2003. The study is conducted as part of a series of small experimental burns to study biomass combustion and carbon release rates from deforested Amazon forest. This particular study monitored the change in vulnerability to fire on the interface between primary forest and recent deforested patches near Alta Floresta in Mato Grosso. The objective of the study is to identify the conditions necessary to self-sustain fire spread in closed-canopy forests in the seasonally dry Amazon forest. The purpose of establishing the flammability experiment on the edge of the biomass combustion experimental burns is also to measure the effect of heating from burning in adjacent clearings on the flammability of primary forest fuels and to use the fire from the slash burn as the ignition source for the understory fire.

The experiments occurred in "terra firme" forest sites located near the city of Alta Floresta, Mato Grosso, Brazil. Alta Floresta is located in a region that experiences one of the highest rates of deforestation and fire occurrence. In 2002, Brazil's fire regulations allowed burning only after October 1 in 2002, by then the rainy season had started, which did 
not allow a successful burning. In 2003, a wildfire that escaped from a nearby pasture fire burned without control in the forest understory for several days and burned the experimental plot before the planned burn date. Results regarding biomass consumption and carbon release rates of the 1997-1999 set of tests have been published by Carvalho et al. (2001). All the experiments followed the same procedure of previous ones carried out in Manaus, Amazonas (Carvalho et al., 1995, 1998), and in Tomé Açu, Pará (Araújo et al., 1999).

During the experiment, we monitored fuel moisture, microclimate, regional weather, and changes in canopy closure. The monitoring occurred along a perpendicular transect from the deforested patch into the forest for the entire dry season from timber felling day in May until the experimental burns occurred in late August/early September. This loggingdrying-burning protocol is a common practice used by farmers in Amazonia. During the slash fire, we monitored fire behavior and depth of fire spread in the undisturbed forest from the edge of land clearing.

A transect consisted of the following monitoring stations: the center of the deforested patch for the combustion experiments, the edge between the deforested patch and the forest $(0 \mathrm{~m}), 15$ meters, 30 meters, and 45 meters from the edge. The transects were installed before the tree felling, the equipment was picked up for the tree felling and reinstalled the day after the felling.

Litter moisture was monitored by placing litter from the site in nylon mesh bags. The bags were weighted three times a week. Litter was replaced several times during the season and oven-dried to obtain moisture content. Three sets of 10-hour fuel sticks were placed in the monitoring station and weighted at the same time than the litter. One air temperature/relative humidity sensor (Hobo $\left.{ }^{\circledR}\right)$ was installed per station. Temperature and relative humidity was monitored every hour for the entire duration of the experiment. We used the LAI-2000®, Plant Canopy Analyzer to monitor changes in leaf area index every seven days from June to September. Few days before the fire, a firebreak line was constructed at a variable distance (up to 100 meters) from the edge from the deforested patch to ensure that an accidental fire would not escape into neighboring pastures. Fire ignition for the understory fires in the undisturbed fire came form the burning patch where the combustion experiments were conducted. A paper by Andrade and others in these proceedings reports fire characteristics from those fires. Understory fires were monitored until they extinguished or were mopped-up when they reached the firebreak line.

\section{DEFORESTATION, \\ LANDSCAPE FRAGMENTATION, LOGGING AND FIRE HAZARD IN TROPICAL FORESTS}

\section{Landscape Fragmentation and Fire}

Over the last 30 years, the international science community has focused in Brazil because of the global impact of deforestation, landscape fragmentation, fire vulnerability, and smoke emissions. The Brazilian Amazon experienced a high rate of deforestation in the $70 \mathrm{~s}$, however, current estimates provided by the Brazil's Instituto Nacional de Pesquisas Espaciais (INPE) (INPE 2002; INPE 2003) signal that it is still a difficult problem to solve. INPE estimates that the deforestation rate for the 2000/2001 reached 18,166 squared kilometers. INPE also estimates that during 1995, 20.5 million hectares of the Brazilian Legal Amazon burned. Extensive deforestation in the Amazon basin has created a highly fragmented forest in regions with an extensive rate of land use conversion and use of fire for land clearing and agriculture and grassland maintenance.

The forest on the interface with land clearings suffers drastic changes in micro weather, vegetation composition and structure, and ecological processes. Those altered vegetation and environmental conditions of the interface are favorable for allowing sustaining combustion under the forest canopies after a prolonged dry season. The threshold conditions for fire spread and the characteristics of fire in the tropical forests of the Brazilian Amazon are important determinants of fire effects on the ecosystem and biogeochemical cycles. The combination of increased fire usage, larger areas of forest vulnerable to fire, and predicted severe droughts under several climate change scenarios creates a potential threat to the 
integrity and sustainability of the tropical Amazonia and elsewhere in the tropical world.

These recently created interfaces suffer drastic microclimate changes soon after the tree felling during the land clearing practices. The data collected from the experiments shows the immediate effect in temperature for the first four days after the land clearing. Relative humidity also shows a similar pattern. For the first few days, the effects can be detected only on the edges and for a few meters inside the forest. However, as the dry season continues, the drier and warmer conditions can be experienced deeper into the forest. For those first few days, the air temperature at mid-day on the edges can be five degrees higher than deeper into the forest. Difference in air relative humidity for the same hours can be up to $40 \%$ between the edge and inside the forest. Under those conditions, fuels start to become drier. However, because the land clearings occur mostly at the end of the rainy season in this region, there is enough air humidity at night to recharge ambient, soil, and fuel moisture. Consequently, flammability increase on these few days may not be significant. Additionally, fuels on the recent land clearing will be green and will not ignite. This statement will likely not hold true if the land clearing was created in a previous years and the fuels have cured for long time. Thus, in that case, only a short drying period may be needed to ignite cured biomass in land clearing from previous years.

Difference between the edge and inside the forest becomes sharper by the end of the dry season. Average air temperature at 45meters inside the forest can be 10 degrees lower than the edge and relative humidity can be $30 \%$ higher inside the forest from 11 AM to 3 PM. Hourly trends of air temperature and relative humidity reached a maximum between 11 and 3 PM. However, minima were observed between 5 and 6 AM. Leaf area index also decreases seasonally but is more evident near the edges. Although the correlation of flammability with leaf area index is not as strong as expected, it shows a decreasing trend. Moreover, cold front passages also causes leave shedding, a phenomenon that was observed in 1999 during a short term cold front passage, the leaf area index showed a noticeable decrease because of the leaf shedding due to a drastic drop in temperature.
A decrease in leaf area index may be reflected in the availability of more litter fuel on the forest floor available for an understory fire.

The micro weather conditions along the transect are also reflected in differences in fuel moisture content. Similarly to relative humidity and temperature, fuel moisture for the 10-hour sticks follows the same pattern. The driest fuel conditions are registered at the center of the experimental land clearing, followed by the edge. Inside the forest, the difference between 30 and 45 meters is evident only when it is dry. Early in the dry season, the fuel moisture difference between those two points is not evident. Similar patterns were also observed in litter moisture.

Fires that burned in the understory from the experimental land clearing fires can penetrate for only a few meters to over 100 meters inside the forest in these recently created interfaces. Figure 6 shows a pattern of fire-spread depth from the land clearing edge. During extreme dry years, or when the land clearings are adjacent to old land clearings, as it was observed in 1997, fire depth can reach up to 200 meter of depth from a $100 \mathrm{~m} \times 100$ $\mathrm{m}$ slash fire plot. We have observed forest fires in the region that escape from grassland fires and propagate in the understory for several kilometers, mostly by the end of the dry season. Fires that escape into the forest understory from pastures or slash burns usually exhibit a slow rate of spread. These slow spreading fires represent a challenge for the current fire behavior models because the flames spread under very limiting conditions, similar to those observed in Alta Floresta. Description of the observed fire behavior is presented by Andrade and others in these proceedings.

\section{Logging and Fire}

Little is known on the effects of deforestation and logging on fire vulnerability of the primary and secondary forests not only along the Amazonian arc of deforestation or ecotones with savanna type vegetation, but also in the interior Amazon basin where forest may be wetter. Ordinarily, undisturbed tropical rain forest is considered a non-flammable ecosystem. Nevertheless, paleoecological evidences show that fires have occurred for thousands of years $(7,000$ to 4,000 years and 
during the Holoceno) on these ecosystems throughout the tropical world (Cordeiro and others 2000; Saldarriaga and West 1986, Sanford et al. 1985). Cordeiro and colleagues suggest that the recent carbon deposition associated with land use change in Alta Floresta is similar to carbon deposited during the Holocene drought. Models that predict global climate change forecast that those extreme climate conditions may be more recurrent in the future. Although fires in the tropical ecosystems have been scarcely studied, several investigations are under way to identify the conditions that make the forest flammable and allow the fuels to sustain fire spread, and to evaluate the reduction of fire hazard in forest stands under the low impact harvesting regimes for several years after the logging. Similar experiments will be started in 2004 in the tropical deciduous forests of Bolivia.

Trees in temperate forests have developed fire resistance. However, trees in tropical forests do not have those features. Therefore, even a low intensity fire is lethal for many of the tree species. Undisturbed evergreen tropical forests are able to maintain dense lush leaf canopies during the drought season throughout Amazônia that may extend up to 5 months (Nepstad et al. 1994). That condition prevents litter, downed woody fuels, and understory vegetation of reaching the low moisture contents that make it fire susceptible. In normally drier sub regions along the "Arc of Deforestation", or ecotones with the savanna type vegetation, trees shed leaves to conserve moisture during very dry periods, allowing more sunlight and wind to penetrate the canopy and hasten the drying of fuels. This effect is more evident on the forests along the edges of land clearings where agriculture and ranching are practiced in a permanent basis.

Pressure on the Amazon forest will continue increasing as a natural response to Brazilian population growth, and to sustain the population already living in the basin. Fires set to clear land for agriculture and pastures often spread into adjacent logged areas and even into the primary forests, and many of these forests will not then regenerate to their original condition. It is to be hoped that some of the negative impacts will be relieved by the application of improved management techniques, such as low-impact harvesting, and the more judicious use of fire.

Land clearing and harvest of moist tropical forests inevitably increases the risk of destructive forest fires on the remaining forests. The potential to intensify the fire regime so severely that tropical forests are irreversibly replaced by Cerrado or other biomes is a serious problem in ecotonal areas along the "Arc of Deforestation" extending from eastern Pará to central Bolivia (Negreiros et al. 1998).

Replication of such an intensive studies is almost impossible. Thus, when regional or global assessments of flammability, smoke emissions are needed, results from fire studies in Alta Floresta can be extrapolated to relatively similar regions in the tropical world.

\section{REFERENCES}

Araújo, T.M.; Carvalho, J.A.; Higuchi, N.; Brasil, A.C.P.; Mesquita, A.L.A., A tropical rainforest clearing experiment by biomass burning in the state of Pará, Atmospheric Environment., 33(13), 1991-1998, 1999.

Cairns, M. A.; W. M. Hao; E. Alvarado; P. K. Haggerty. 2000. Carbon emissions from spring 1998 fires in tropical Mexico. In Proceedings of the Joint Fire Conference and Workshop: Crossing the Millennium: Integrating Spatial Technologies and Ecological Principles for a New Age in Fire Management. June 15-17, 1999. Boise Idaho. The University of Idaho. Vol. I. pp. 242-248.

Carvalho, J.A.; J. M. Santos; J. C. Santos; M. M.; N. Higuchi. 1995. A tropical rainforest clearing experiment by biomass burning in the Manaus region, Atmospheric Environment, 29, 2301-2309.

Carvalho J.A.; N. Higuchi; T. M. Araújo; J. C. Santos. 1998. Combustion completeness in a rainforest clearing experiment in Manaus, Brazil, Journal of Geophysical Research, 103(D11), 13,195-13,200.

Carvalho J.A.; F. S. Costa; C. A. G. Veras; D. V. Sandberg; E. C. Alvarado; R. Gielow; A. M. Serra; J. C. Santos. 2001. Biomass fire consumption and carbon release rates of rainforest-clearing experiments conducted in 
Northern Mato Grosso, Brazil, Journal of Geophysical Research.

Cordeiro, R. C.; B. Turcq; A. Sifeddine; J. A. Capitâneo; A. O. da Silva. 2000. Incêndios Amazônicos: uma abordagem em diferentes escalas de tempo. In. LBA First Scientific Conference. Belem, Para. June 26-30, 2000. Pag. 221.

Crutzen, P.J.; M. O. Andreae. 1999. Biomass Burning in the Tropics: Impact on Atmospheric Chemistry and Biochemical Cycles. Science, 250:1669-1678.

Fearnside, P. M. 1990. Fire in the tropical rain forest of the Amazon basin. In Fire in the Tropical Biota. Ecological Studies, Vol. 48. Edited by J. G. Goldammer, pp 106-116. Springer-Verlag, New York.

Fearnside, P.M. 2000. Global Warming and Tropical Land-use Change: Greenhouse Gas Emissions from Biomass Burning, Decomposition and Soils in Forest Conversion, Shifting Cultivation and Secondary Vegetation. Climatic Change, 46(1-2):115158.

INPE. 2003. Preliminary data on deforestation for 2001-2003 in the Brazilian Amazon forest. Data obtained from http://www.obt.inpe.br/prodes_2001_2002. htm.

INPE. 2002. Monitoreamento da Floresta Amazonica Brasileira por Satelite. Relatorio ano 2000-2001. Data available at http://www.inpe.br/Informacoes_Eventos/

Kirchhoff, V.W.J.H; Escada, P.A.S. 1998. O megaincendio do seculo/The wildfire of the century: 1998. TRANSTEC Editorial, Sao Jose dos Campos, SP.

Kauffman, J.B.; D. L. Cummings; D. E. Ward; R. Babbitt. 1995. Fire in the Brazilian Amazon: Biomass, Nutrient Pools, and Losses in Slashed Primary Forests. Oecologia, 104:397-408.
Laurance W. F.; M. A. Cochrane; S. Bergen; P. M. Fearnside; P. Delamonica; C. Barber; S. D'Angelo; and T. Fernandes. 2001. The future of the Brazilian Amazon. Science 2001 5503(291): 438-439.

Negreieros, G.H.; D. Nepstad; D. Sandberg; E. Alvarado; T. Hinckley; M. Pereira. 1998. Fire along transition between the Amazon forest and the Cerrado ecosystems. In: Proceedings of the 13th conference on fire and forest meteorology; 1996 October 24- November 2; Lorne, Australia.

Nepstad, D. C.; C. R. de Carvalho; E. A. Davidson; P. H. Jipp; P. A. Lefebvre; G. H. de Negreiros; E. D. Silva; T. A. Stone; S. E. Trumbore; S. Vieira. 1994. The role of deep roots in the hydrological and carbon cycles of Amazonian forests and pastures. Nature 372: 666-669.

Nepstad, D. C.; A. G. Moreira; A. A. Alencar. 1999. Flames in the Rain Forest: Origins, impacts and alternatives to Amazonian Fire. The Pilot Program to Conserve the Brazilian Rain Forest. 190 p

Saldarriaga, J. G.; D. C. West. 1986. Holocene fires in the northern Amazon basin. Quaternary Research 26:358-366.

Sanford R. L.; J. Saldarriaga; K. E. Clark; C. Uhl; R. Herrera. 1985. Amazon rain forest fires. Science 227:53-55.

Skole, D.; C. Tucker. 1993. Tropical deforestation and habitat fragmentation in the Amazon: Satellite data from 1978 and 1988. Science 260(25 June): 1905-1910

Uhl, C.; J. B. Kaufman. 1990. Deforestation, fires susceptibility, and potential tree responses to fire in the Eastern Amazon. Ecology, 71(2): 437-449. 